\title{
Temperature affects coral disease resistance and pathogen growth
}

\author{
Jessica R. Ward ${ }^{1,3, *}$, Kiho Kim² ${ }^{2}$ C. Drew Harvell ${ }^{1}$ \\ ${ }^{1}$ Department of Ecology \& Evolutionary Biology, Cornell University, Ithaca, New York 14853, USA \\ ${ }^{2}$ Biology Department, American University, Washington, DC 20016, USA \\ ${ }^{3}$ Present address: Marine Biology Research Division, Scripps Institution of Oceanography, \\ University of California San Diego, La Jolla, California 92093, USA
}

\begin{abstract}
Temperature anomalies on coral reefs now routinely exceed coral stress thresholds, making temperature a critical variable to consider in coral host-pathogen systems. While temperature is widely hypothesized to drive coral disease outbreaks by decreasing coral resistance and increasing pathogen growth rates, tests of the temperature hypothesis are rare. Here we report evidence from the sea fan coral Gorgonia ventalina-Aspergillus host-pathogen system that temperature stress increases one component of sea fan resistance. Experimentally infecting sea fan fragments while increasing temperatures to reflect summertime highs in the Florida Keys, USA, caused a $176 \%$ increase in activity of host-derived antifungal compounds. Thus, temperature stress and infection induce higher levels of resistance. However, pathogen growth rate also increases over the same temperature range, providing an opportunity for pathogen establishment before host resistance is maximal. This dual effect of temperature emphasizes the need to test intact host-pathogen systems. Given predictions for future warming events, aspergillosis is predicted to continue causing sea fan mortality in the Caribbean Sea.
\end{abstract}

KEY WORDS: Temperature · Climate - Disease - Resistance - Sea fan · Gorgonia ventalina . Aspergillus sydowii $\cdot$ Infection

\section{INTRODUCTION}

Two opposing forces regulate the outcome of hostpathogen interactions: pathogen virulence (the ability of a pathogen to infect or spread within a host) and host resistance to infection. The abiotic environment can affect either or both sides of this balance, shifting the interaction in favor of the pathogen or host (Blanford et al. 2003, Thomas \& Blanford 2003). Temperature in particular can affect the outcome of insectfungus host-pathogen interactions (Blanford et al. 2003) and host-pathogen interactions in ectotherm vertebrates such as amphibians (Jackson \& Tinsley 2002) and fish (Le Morvan et al. 1998).

Recent increases in marine diseases are hypothesized to be driven, in part, by increased sea surface temperatures (Harvell et al. 2002, Ward \& Lafferty
2004), which can stress hosts, increase their susceptibility to infection, and ultimately alter population dynamics of disease (Lafferty \& Holt 2003). In particular, some coral disease outbreaks are associated with temperature warming, from either seasonal or temperature anomalies (Harvell et al. 2001, Kuta \& Richardson 2002, Jones et al. 2004). However, tests of the temperature hypothesis are rare (Israely et al. 2001, Cervino et al. 2004) in part due to the intractability of many coral disease systems in which pathogens are not yet identified (Sutherland et al. 2004).

We used aspergillosis of sea fan corals Gorgonia ventalina, caused by the fungus Aspergillus sydowii (Geiser et al. 1998), as a model system to test the effects of temperature on an intact coral-pathogen system in the Caribbean Sea. Aspergillosis was documented in the Caribbean in 1995 with prevalence 
exceeding $90 \%$ at some sites (Nagelkerken et al. 1997). Disease prevalence and severity (the amount of tissue lost due to disease per colony) have been monitored since 1997 in the Florida Keys, USA (Kim \& Harvell 2004). More than $50 \%$ of sea fan tissue in the Florida Keys has been lost due to complete or partial disease-induced mortality (Kim \& Harvell 2004). Optimal pathogen virulence, quantified as maximum growth rate, is near $30^{\circ} \mathrm{C}$ (Alker et al. 2001). These temperatures regularly occur in the Florida Keys from May to October (Fig. 1) and may promote new infections or facilitate pathogen spread within an infected colony (i.e. increase severity).

Infection with Aspergillus sydowii induces a generalized host resistance response that includes a suite of physical and chemical defenses (Dube et al. 2002, Petes et al. 2003, Alker et al. 2004). One component of the resistance response is production of antifungal compounds near the site of infection (Kim et al. 2000). This response is likely affected by temperature as sea fans are thermoconformers (i.e. they do not actively regulate body temperature and therefore track ambient temperature) and previous work with thermoconforming insects indicates that the innate immune response is sensitive to temperature (reviewed in Thomas \& Blanford 2003).

Because temperature could influence both pathogen virulence and host resistance, it is important to test the intact host-pathogen interaction over a range of temperatures. The Gorgonia-Aspergillus system is a tractable marine host-pathogen system with which to test the effects of temperature as the hosts are abun-

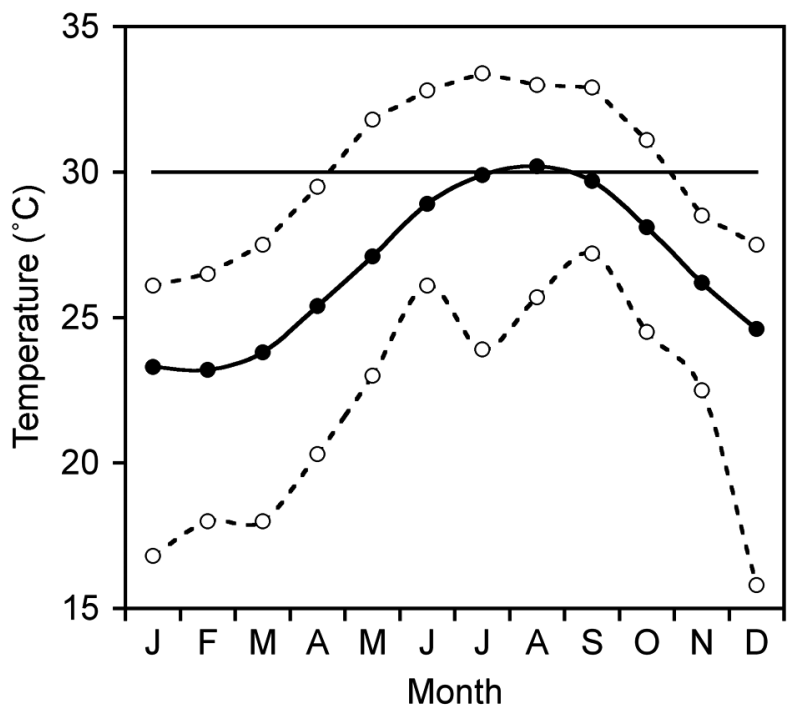

Fig. 1. Sea surface temperature in the Florida Keys, USA. Data are from the National Data Buoy Center, Stn SMKF1, Sombrero Key, Florida (from 1998 to 2001). Mean (@), maximum and minimum (O) sea surface temperature in each month. Horizontal line corresponds to $30^{\circ} \mathrm{C}$ dant, the pathogen is in culture, and hosts can be successfully infected in the laboratory. We predicted that temperature stress would decrease sea fan resistance, making sea fans more susceptible to fungal infection, while increasing pathogen growth rate. Here we report results of temperature-controlled experiments and discuss these results in the context of the current epizootic and climate change.

\section{MATERIALS AND METHODS}

Samples were collected in August 2001 from moderately sized (30 to $60 \mathrm{~cm}$ ), healthy sea fans at Eastern Sambo Reef in the Florida Keys, USA $\left(24^{\circ} 29.74^{\prime} \mathrm{N}\right.$, $81^{\circ} 38.92^{\prime} \mathrm{W}$ ). We collected four $36 \mathrm{~cm}^{2}$ fragments from the outer margin of each of 18 sea fan colonies. In all cases, 1 fragment was processed (see below) immediately to establish initial conditions. Of the remaining 3 fragments, one was placed into each temperature treatment $\left(27,30\right.$ or $\left.31.5^{\circ} \mathrm{C}\right)$ at Mote Marine Tropical Research Laboratory on Summerland Key, Florida. Of the 18 fragments in each of the 3 temperatures, 9 were randomly blocked within infection groups and the remaining 9 in control groups. Temperature was maintained within $\pm 0.5^{\circ} \mathrm{C}$ of target temperatures using a freshwater water bath circulating through a heater/ chiller and around $38 \mathrm{l}$ aquaria filled with seawater collected from the reef. Each tank was a closed system to prevent pathogen release to the environment.

Fragments were acclimated for at least $24 \mathrm{~h}$ before experimental infection. In each temperature treatment, 9 fragments were inoculated with Aspergillus sydowii using gauze strips covered with agar and fungus, pushed through $1 \mathrm{~cm}$ slits cut in the sea fan mesh. The remainder received control gauze/agar strips with no fungus. Control and treatment gauze strips were left on fragments for $7 \mathrm{~d}$ at which time each fragment was processed for zooxanthellae abundance and crude extract antifungal activity (a measure of host resistance; Kim et al. 2000).

Zooxanthellae abundance. A $1 \mathrm{~cm}$ diameter piece of tissue from each fragment was homogenized in $1 \mathrm{ml}$ seawater using a Kontes 22 glass homogenizer and Teflon pestle attached to a variable speed power drill. Tissue homogenate was washed twice with seawater and resuspended in $1 \mathrm{ml}$ of $5 \%$ formalin. Four $30 \mu \mathrm{l}$ aliquots were removed from each sample, stained with $2.75 \mu \mathrm{l} \mathrm{Lugol's} \mathrm{solution,} \mathrm{and} \mathrm{counted} \mathrm{on} \mathrm{a} \mathrm{brightline}$ hemacytometer at $40 \times$ magnification.

Fungal inhibition. Fungal inhibition of crude extracts was tested with methods modified from Alker et al. (2001) and Dube et al. (2002). Crude antifungal compounds were extracted from $16 \mathrm{~cm}^{2}$ tissue samples twice overnight at $-20^{\circ} \mathrm{C}$ in dichloromethane (DCM), 
which was then evaporated under continuous $\mathrm{N}_{2}$ flow. Extracts were weighed and resuspended in acetone to a final concentration of $20 \mathrm{mg} \mathrm{ml}^{-1}$. All extracts were tested at an incubation temperature of $27^{\circ} \mathrm{C}$, regardless of the temperature at which the sea fan fragments were held in the aquaria. This allowed comparison of activity of extracts across temperature treatments without the confounding effects of differences in fungal growth rates at different incubation temperatures.

We added $75 \mu$ l of each extract suspension to the surface of 3 replicate $35 \mathrm{~mm}$ diameter Petri plates containing peptone yeast glucose (PYG) agar (1 l deionized water, $1.25 \mathrm{~g}$ peptone, $1.25 \mathrm{~g}$ yeast extract, $3.0 \mathrm{~g}$ glucose, $30 \mathrm{~g}$ Instant Ocean ${ }^{\circledR}, 20 \mathrm{~g}$ bactoagar, $0.05 \mathrm{~g}$ tetracycline) and spread with a glass rod. Unamended agar plates, acetone-amended plates, and plates with hygromycin (an antifungal agent) served as controls. We placed $2 \mu \mathrm{l}$ of stock spore solution (2250 spores $\mathrm{ul}^{-1}$ ) in the center of each plate. Plates were closed with the self-sealing film, Parafilm, and incubated at $27^{\circ} \mathrm{C}$ for $6 \mathrm{~d}$.

Digital images of circular fungal colonies were taken 4, 5, and 6 d post-inoculation to avoid a short lag in colony growth that occurs after inoculation (Alker et. al. 2001). Fungal colony area was calculated from 2 perpendicular measurements of colony diameter with digital imaging software (NIH Image v 1.62, National Institutes of Health). Antifungal activity was calculated as inhibition of fungal growth on extract-amended plates relative to unamended and acetone-amended control plates (Dube et al. 2002) as follows:

$$
I=1-\left(\frac{\text { Area }_{\text {extracts }}}{\text { Area }_{\text {controls }}}\right)
$$

where Area $_{\text {extracts }}=$ area of fungal colonies on extract-

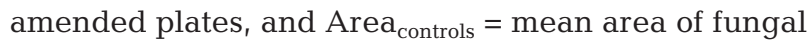
colonies on unamended and acetone-amended control plates. Both sets of control plates were used since there was no difference in fungal growth on the unamended and acetone-amended plates (data not shown). The change in inhibition from initial fragments was used in analyses $\left(\Delta I=I_{\text {Final }}-I_{\text {Initial }}\right)$.

Zooxanthellae abundance in healthy and naturally infected colonies. To determine the abundance of zooxanthellae in field collected healthy and diseased colonies, a $1 \mathrm{~cm}$ diameter tissue sample was collected from 20 healthy colonies and from diseased areas of 20 naturally infected colonies at Pickles Reef (245 59.08' N, $80^{\circ} 24.98^{\prime} \mathrm{W}$ ). A second sample was taken from a healthy area of each diseased colony approximately $10 \mathrm{~cm}$ from the infection. Tissue samples were processed using zooxanthellae abundance procedures described above.

Data analysis. The change from the initial value for each dependent variable was used in all analyses. Data were tested for normality (Shapiro-Wilk) and homo- geneity of variances (Levene) before analysis. A correlation matrix revealed no covariation between zooxanthellae abundance and antifungal activity, so each was analyzed in a separate 2-way nested ANOVA (temperature, infection) with fan as a random effect nested within infection to account for variability among colonies (SAS, v. 8, Copyright 2001, SAS Institute).

\section{RESULTS}

\section{Zooxanthellae abundance}

Both temperature and infection affected the abundance of zooxanthellae in sea fan tissue (Fig. 2; temperature $F=139.85$, p $<0.0001$; infection $F=21.05, \mathrm{p}=$ 0.0003 ; temperature $\times$ infection $F=4.30, \mathrm{p}=0.0148$ ). The combination of thermal stress $\left(31.5^{\circ} \mathrm{C}\right)$ and infection resulted in a $31.4 \%$ loss of zooxanthellae (TukeyKramer post-hoc tests $\mathrm{p}<0.0001)$. In all other treatments, zooxanthellae increased with the largest increase occurring in $27^{\circ} \mathrm{C}$ control fragments $(105.5 \%)$ and the smallest in $31.5^{\circ} \mathrm{C}$ control fragments $(19.7 \%$; Tukey-Kramer post-hoc tests $\mathrm{p}<0.0001)$. All infected fragments contained fewer zooxanthellae than respective controls (Fig. 2).

Field surveys indicated that similar losses in zooxanthellae occurred in naturally infected sea fans (Fig. 3). Healthy sea fans contained more zooxanthellae than healthy areas of diseased sea fans. Healthy areas of

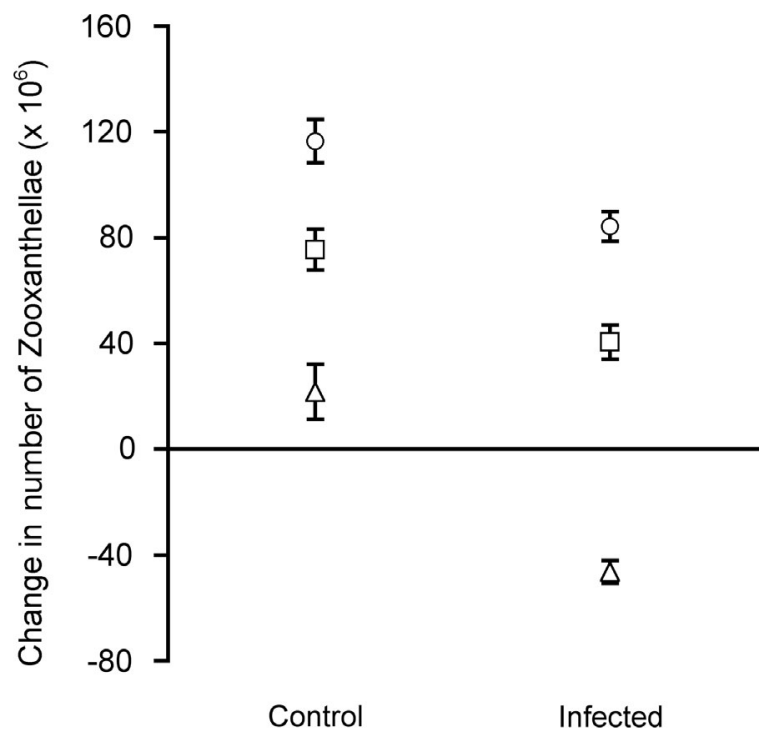

Fig. 2. Gorgonia ventalina. Change in zooxanthellae abundance $( \pm$ SE) in control and experimentally infected sea fan fragments maintained at 3 temperatures. Change is calculated as the difference in number of zooxanthellae in $1 \mathrm{~cm}$ diameter tissue samples. $\mathrm{O}=27^{\circ} \mathrm{C} ; \square=30^{\circ} \mathrm{C} ; \Delta=31.5^{\circ} \mathrm{C}$ 


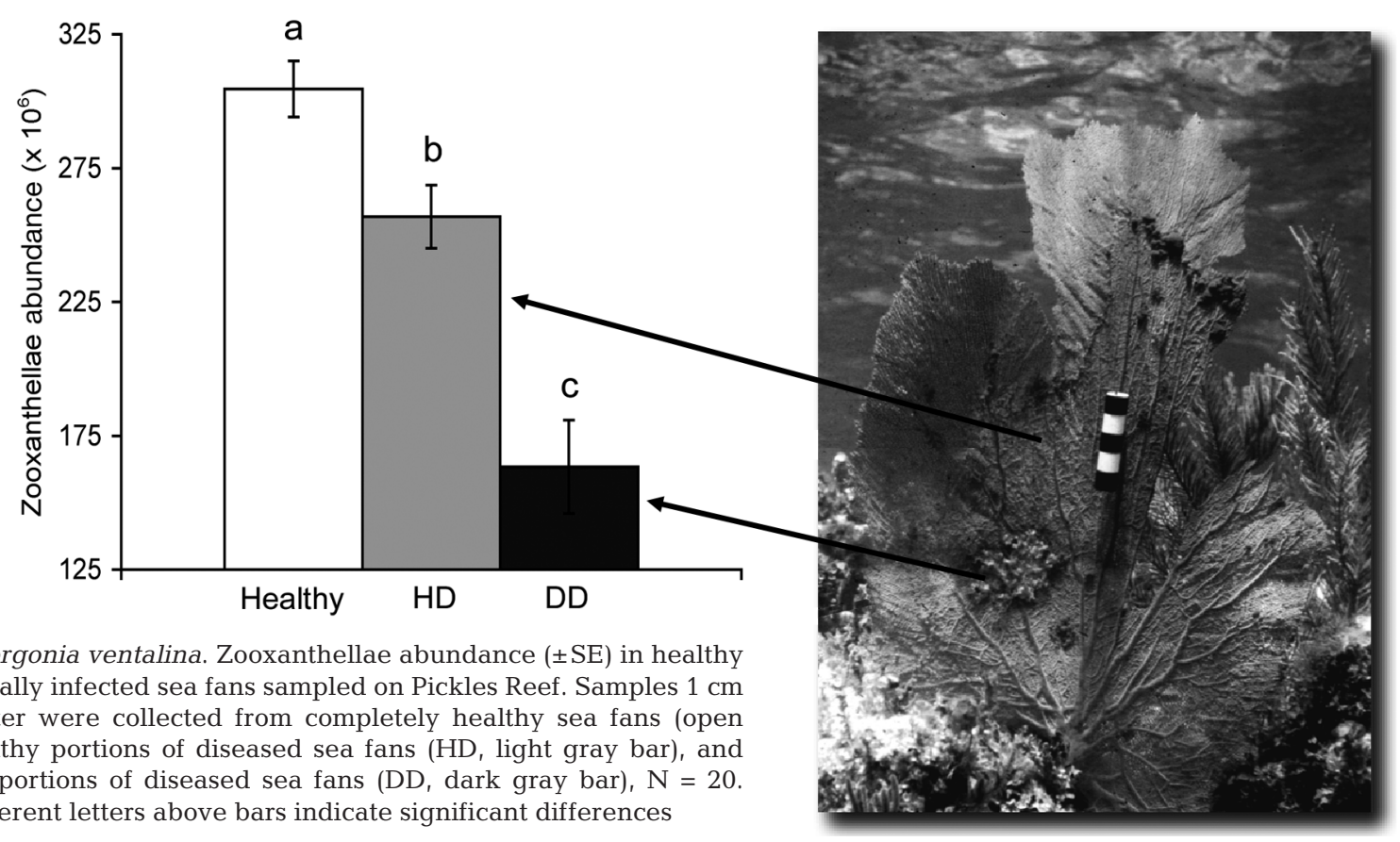

diseased sea fans in turn contained more zooxanthellae than diseased areas of diseased sea fans (ANOVA, $F=98.91, \mathrm{p}<0.0001$, Tukey-Kramer post-hoc tests $\mathrm{p}<$ $0.0001)$.

\section{Fungal inhibition}

Temperature and infection affected inhibitory activity of host-derived extracts with a significant temperature $\times$ infection interaction (Fig. 4 ; temperature $F=$ $4.91, \mathrm{p}=0.009$; infection $F=5.85, \mathrm{p}=0.03$; temperature $\times$ infection $F=9.57, \mathrm{p}=0.0001$ ). Little to no change in inhibition occurred in controls while inhibition increased in all infected fragments. The greatest increase in inhibition occurred in infected fragments at the warmest $\left(31.5^{\circ} \mathrm{C}\right)$ temperature (Tukey-Kramer post-hoc tests $\mathrm{p}<0.05$ ).

\section{DISCUSSION}

Understanding the mechanisms underlying hostpathogen interactions, including the synergistic roles of abiotic stressors and disease, is essential to predict and mitigate disease outbreaks (Lafferty \& Holt 2003). In corals, which live near their upper thermal thresholds on many reefs (Porter \& Tougas 2001), host and pathogen performance curves may peak at different temperatures, with pathogen optima occurring at higher temperatures than host optima (i.e. host resis- tance is lower than pathogen growth or virulence; Fig. 5A). Pathogens may also adapt to temperature increases more rapidly than their hosts due to more rapid growth (Chubb 1980) and shorter generation times (Pojmanska et al. 1980).

Counter to the prediction, we found that sea fan host resistance (measured as inhibitory activity of crude extracts) was almost 2 -fold greater at warmer $\left(31.5^{\circ} \mathrm{C}\right)$ relative to cooler $\left(27\right.$ and $\left.30^{\circ} \mathrm{C}\right)$ temperatures $7 \mathrm{~d}$ post-

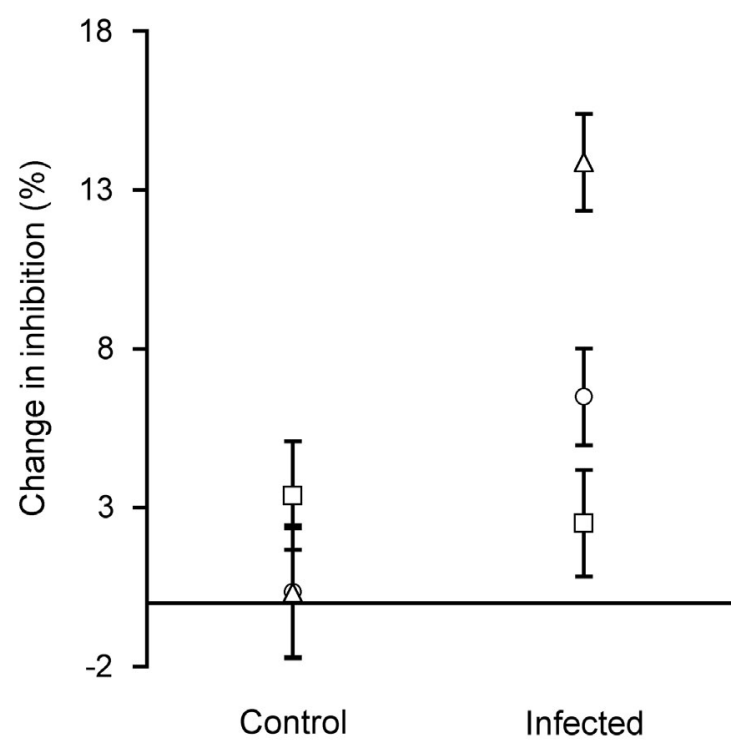

Fig. 4. Gorgonia ventalina. Change in extract inhibition activity ( \pm SE). $\mathrm{O}=27^{\circ} \mathrm{C} ; \square=30^{\circ} \mathrm{C} ; \Delta=31.5^{\circ} \mathrm{C}$ 


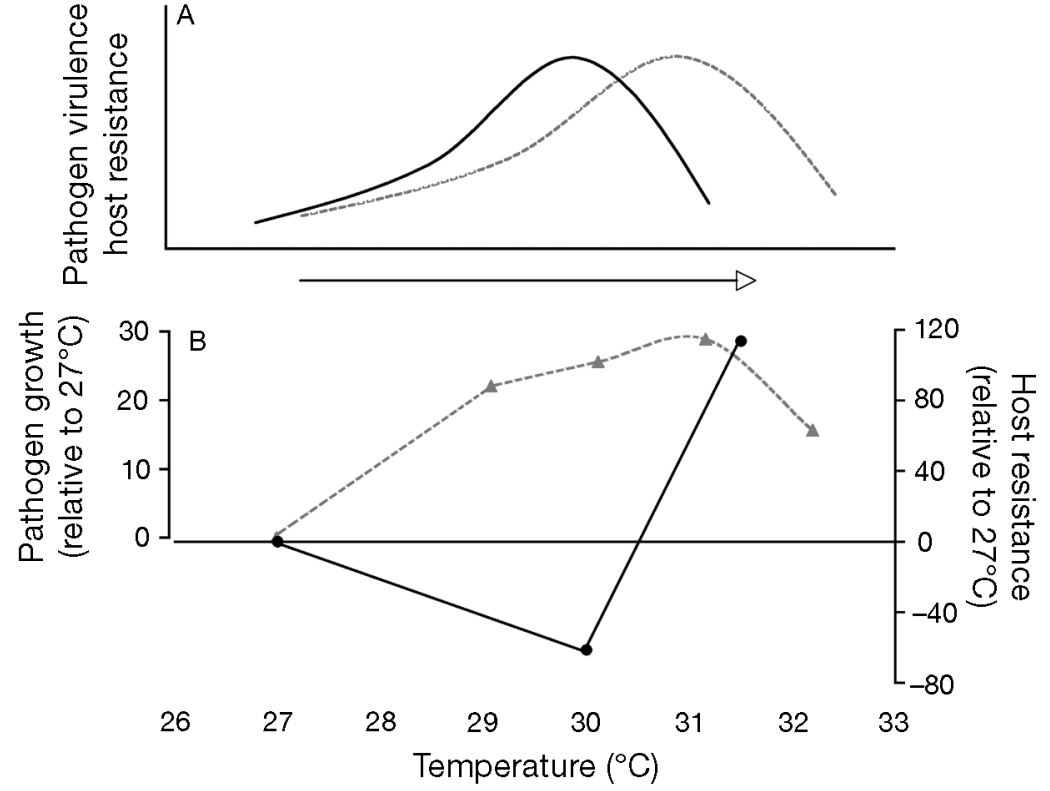

Fig. 5. Gorgonia ventalina and Aspergillus sydowii. Response of host resistance (solid line; measured as extract fungal inhibition activity) and pathogen virulence (dashed line; measured as growth rate) to temperature (schematic scale). (A) Predicted response of host optimum occurring at a lower temperature than pathogen optimum. (B) Observed host and pathogen responses with pathogen growth increasing more rapidly than host resistance. Data for host resistance are from experimentally infected fragments only

infection (Fig. 4). The pathogen is also temperature sensitive, growing $>25 \%$ more rapidly at 30 to $31^{\circ} \mathrm{C}$ than at $27^{\circ} \mathrm{C}$ (Fig. 5B). This may provide an opportunity for the pathogen to infect a host at summer temperatures (near $30^{\circ} \mathrm{C}$, Fig. 1) that promote pathogen growth but not host resistance (Fig. 5B). Once established, the pathogen is concentrated in the proteinaceous gorgonin axis (Petes et al. 2003) where it may avoid host antifungal compounds circulating in the coenenchyme.

It is also possible that host resistance is not constant through time. In some instances, after induction of a response to herbivores or pathogens, a relaxation in the response occurs. Evidence from other studies suggests that sea fan host resistance does not decline over time as the activity induced in warm $\left(31.5^{\circ} \mathrm{C}\right)$ infected fragments is comparable to that found near disease lesions on naturally infected sea fans (Kim et al. 2000, Dube et al. 2002). The naturally infected sea fans were likely infected for weeks to months before sampling, given lesion formation and amount of tissue purpling apparent. This indicates that induced levels of antifungal activity are sustainable over time.

An essential component of coral health is the association of the coral animal with endosymbiotic zooxanthellae. Zooxanthellae increased in all control and in the cooler $\left(27\right.$ and $30^{\circ} \mathrm{C}$ ) infected fragments (Fig. 2).
The increase may have occurred as autotrophy increased to compensate for reduced heterotrophy, (i.e. acquisition of energy from phyto- and zooplankton; Ribes et al. 1998) since closed-system tanks were not amended with plankton during the experiment. The increase in zooxanthellae may also have been in response to wounding as zooxanthellae densities have been shown to peak at wound sites on a related gorgonian coral 7 d post-injury (Meszaros \& Bigger 1999). If so, this suggests an important role of temperature in regulating wound healing in gorgonian corals.

Both temperature and infection affected the magnitude of changes in zooxanthellae abundance, with a significant temperature $\times$ infection interaction. This was particularly evident in the loss of zooxanthellae with infection at the warmest $\left(31.5^{\circ} \mathrm{C}\right)$ temperature (Fig. 2). Naturally infected sea fans sampled on the reef also have fewer zooxanthellae, in both healthy and diseased areas of the infected sea fan, relative to those in completely healthy sea fans (Fig. 3), suggesting that infection causes at least partial bleaching. Reduction of zooxanthellae abundance in infected tissue is likely due to a reduction in number of polyps in infected areas (Kim \& Harvell 2002). It is not possible to distinguish from these data whether lower zooanthellae abundance in healthy tissue of infected colonies occurred before, or was a consequence of, infection.

The fragments infected at $31.5^{\circ} \mathrm{C}$ and naturally infected sea fans had lower zooxanthellae abundances than control fragments or healthy sea fans, respectively (Figs. 2 \& 4). However, high levels of antifungal activity were associated with $31.5^{\circ} \mathrm{C}$ infected fragments (Fig. 4) and lesions on naturally infected sea fans (Kim et al. 2000). These results suggest that zooxanthellae do not play a critical role in production of antifungal compounds. However, the identity of zooxanthellae in coral tissue can be as important as their abundance. Symbiont shuffling, or acquisition of different, more stresstolerant clades, has been suggested as a process of host acclimation to temperature stress (Baker et al. 2004). The effects of temperature and infection on the zooxanthellae clade were investigated in a separate study (Kirk et al. 2005). Symbiont associations were stable and identical in healthy, experimentally infected, and naturally infected sea fans, suggesting that symbiont shuffling does not occur in sea fans regardless of temperature or disease stress (Kirk et al. 2005). 
The factors that control pathogen transmission and spatial distribution of infections in marine systems are often unknown. Sea fan aspergillosis is patchily distributed with high prevalence and severity at some sites, but not others, along the same reef tract (Jolles 2002, Kim \& Harvell 2004). One hypothesis to explain patchiness of aspergillosis is that environmental stressors such as temperature and nutrient enrichment (Bruno et al. 2003) facilitate infections at some sites. Experimentally testing the role of these abiotic factors on host-pathogen interactions may reveal approaches for disease control.

Temperature can have complex effects on disease dynamics (Lafferty \& Holt 2003). In some cases, hosts may become more susceptible to infection while in others they are released from infection (Harvell et al. 2002, Lafferty \& Holt 2003). We found that short-term (i.e. 7 d) thermal stress increases host resistance to infection (quantified as fungal inhibition by crude extracts) in sea fan corals (Fig. 4). However, pathogen growth rate increases more rapidly than host resistance over the same temperature range (Alker et al. 2001). In addition, constitutive levels of host resistance (Kim et al. 2000) and induction of resistance with temperature stress are not uniform within the sea fan colony (J. Ward pers. obs.), providing an opportunity for rapid pathogen infiltration in less-resistant areas of the colony during periods of warm $\left(30^{\circ} \mathrm{C}\right)$ summer temperatures. Prevalence of aspergillosis is currently low in the Florida Keys (Kim \& Harvell 2004). However, given the thermal sensitivity of this hostpathogen system and predictions of more frequent, longer duration thermal anomalies (Hoegh-Guldberg 1999), we predict that this disease will continue to affect sea fans in the Caribbean Sea.

Acknowledgements. We thank A. Shaw, K. Schuster, K. Rypien, J. Andras, J. Bruno, the staff at the Mote Tropical Research Laboratory, especially E. Bartels and B. Smith, S. Santos, and M. A. Coffroth for field support and advice. This work was funded by the Edna Bailey Sussman Fund, Cornell University Field of Zoology, an NSF pre-doctoral fellowship (to J.R.W.), and NSF OCE-0326705 (to C.D.H.). Collections were made under permit \# FKNMS-2004-092.

\section{LITERATURE CITED}

Alker AP, Smith GW, Kim K (2001) Characterization of Aspergillus sydowii (Thom et Church), a fungal pathogen on Caribbean sea fan corals. Hydrobiologia 460:105-111

Alker AP, Kim K, Dube DH, Harvell CD (2004) Localized induction of a generalized response against multiple biotic agents in Caribbean sea fans. Coral Reefs 23:397-405

Baker AC, Starger CJ, McClanahan TR, Glynn PW (2004) Corals' adaptive response to climate change. Nature 430:741

Blanford S, Thomas MB, Pugh C, Pell JK (2003) Temperature checks the Red Queen? Resistance and virulence in a fluctuating environment. Ecol Lett 6:2-5

Bruno JF, Petes LE, Harvell CD, Hettinger A (2003) Nutrient enrichment can increase the severity of coral diseases. Ecol Lett 6:1056-1061

Cervino JM, Hayes RL, Polson SW, Polson SC, Goreau TJ, Martinez RJ, Smith GW (2004) Relationship of Vibrio species infection and elevated temperatures to yellow blotch/ band disease in Caribbean corals. Appl Environ Microbiol 70:6855-6864

Chubb J (1980) Seasonal occurrence of helminths in freshwater fishes. Part III. Larval Cestoda and Nematoda. Adv Parasitol 18:1-120

Dube D, Kim K, Alker AP, Harvell CD (2002) Size structure and geographic variation in chemical resistance of sea fan corals Gorgonia ventalina to a fungal pathogen. Mar Ecol Prog Ser 231:139-150

Geiser DM, Taylor WT, Ritchie KB, Smith GW (1998) Cause of sea fan death in the West Indies. Nature 394:137-138

Harvell D, Kim K, Quirolo C, Weir J, Smith G (2001) Coral bleaching and disease: contributors to 1998 mass mortality in Briareum asbestinum (Octocorallia, Gorgonacea). Hydrobiologia 460:97-104

Harvell D, Mitchell CE, Ward JR, Altizer S, Dobson A, Ostfeld RS, Samuel MD (2002) Climate warming and disease risks for terrestrial and marine biota. Science 296:2158-2162

Hoegh-Guldberg O (1999) Climate change, coral bleaching and the future of the world's coral reefs. Mar Freshw Res 50:839-866

Israely T, Banin E, Rosenberg E (2001) Growth, differentiation and death of Vibrio shiloi in coral tissue as a function of seawater temperature. Aquat Microb Ecol 24:1-8

Jackson JA, Tinsley RC (2002) Effects of environmental temperature on the susceptibility of Xenopus laevis and $X$. wittei (Anura) to Protopolystoma xenopodis (Monogenea). Parasitol Res 88:632-638

Jolles AE (2002) Disease transmission of aspergillosis in sea fans: inferring process from spatial pattern. Ecology 83: 2373-2378

Jones RJ, Bowyer J, Hoegh-Guldberg O, Blackall LL (2004) Dynamics of a temperature-related coral disease outbreak. Mar Ecol Prog Ser 281:63-77

Kim K, Harvell CD (2004) The rise and fall of a six year coralfungal epizootic. Am Nat 164:S52-S63

Kim K, Kim PD, Alker AP, Harvell CD (2000) Chemical resistance of gorgonian corals against fungal infections. Mar Biol 137:393-401

Kirk N, Ward J, Coffroth M (2005) Stable Symbiodinium composition in the sea fan (Gorgonia ventalina) during temperature and disease stress. Biol Bull (Woods Hole) 209:227-234

Kuta KG, Richardson LL (2002) Ecological aspects of black band disease of corals: relationships between disease incidence and environmental factors. Coral Reefs 21:393-398

Lafferty KD, Holt RD (2003) How should environmental stress affect the population dynamics of disease? Ecol Lett 6: 654-664

Le Morvan C, Troutaud D, Deschaux P (1998) Differential effects of temperature on specific and nonspecific immune defences in fish. J Exp Biol 201:165-168

Meszaros A, Bigger C (1999) Qualitative and quantitative study of wound healing processes in the coelenterate, Plexaurella fusifera: spatial, temporal and environmental (light attenuation) influences. J Invertebr Path 73: 321-331

Nagelkerken I, Buchan K, Smith GW, Bonair K and 10 others (1997) Widespread disease in Caribbean sea fans: II. Pat- 
terns of infection and tissue loss. Mar Ecol Prog Ser 160: 255-263

Petes L, Harvell CD, Peters EC, Webb MAH, Mullen KM (2003) Pathogens compromise reproduction and induce melanization in Caribbean sea fans. Mar Ecol Prog Ser 264:167-171

Pojmanska T, Grabda-Kazubska B, Kazubski S, Machalska J, Niewiadomska K (1980) Parasite fauna of five fish species from the Konin lakes complex, artificially heated with thermal effluents, and from Goplo Lake. Acta Parasitol 27: 319-357

Porter JW, Tougas JI (2001) Reef ecosystems: threats to their

Editorial responsibility: Howard Browman (Associate Editorin-Chief), Storebø, Norway biodiversity. Encycl Biodivers 5:73-95

Ribes M, Coma R, Gili JM (1998) Heterotrophic feeding by gorgonian corals with symbiotic zooxanthellae. Limnol Oceanogr 43:1170-1179

Sutherland KP, Porter JW, Torres C (2004) Disease and immunity in Caribbean and Indo-Pacific zooxanthellate corals. Mar Ecol Prog Ser 266:273-302

Thomas MB, Blanford S (2003) Thermal biology in insectparasite interactions. Trends Ecol Evol 18:344-350

Ward JR, Lafferty KD (2004) The elusive baseline of marine disease: are diseases in ocean ecosystems increasing? PLoS Biol 2:542-547

Submitted: January 19, 2006; Accepted: June 2, 2006 Proofs received from author(s): December 18, 2006 